\section{Clinical and Microbiological Evaluation of Surgical and Nonsurgical Treatment of Aggressive Periodontitis}

\author{
Camila Camarinha da Silva Cirino ${ }^{1}$ (D), Hugo Felipe do Vale ${ }^{2}$ (D), Márcio \\ Zaffalon Casati ${ }^{1} \mathbb{B}^{\circ}$, Enilson Antonio Sallum ${ }^{1} \mathbb{D}^{\mathbb{B}}$, Renato Corrêa Viana \\ Casarin $^{1} \mathbb{B}_{\text {, Antônio Wilson Sallum }}{ }^{1}$
}

\begin{abstract}
'Department of Prosthodontics and Periodontics, Piracicaba Dental School, UNICAMP - Universidade Estadual de Campinas, Piracicaba, SP, Brazil ${ }^{2}$ Department of Periodontics, UEA - Universidade do Estado do Amazonas, Manaus, AM, Brazil

Correspondence: Antônio Wilson Sallum, Avenida Limeira 901, 13414-903 Piracicaba, SP, Brasil. Tel: +55-19-2106-5218. e-mail: awsallum@unicamp.br
\end{abstract}

\begin{abstract}
The present study aimed to evaluate clinical and microbiological effects of surgical and nonsurgical periodontal therapy in generalized aggressive periodontitis (GAgP) treatment. Sixteen GAgP patients were included in this randomized split-mouth design clinical trial. Maxillary quadrants were allocated into two groups: Nonsurgical Therapy (NST) and Surgical Therapy (ST). The following clinical parameters were assessed: plaque index $(\mathrm{PI})$, bleeding on probing index $(\mathrm{BoP})$, probing depth (PD), clinical attachment level (CAL) and gingival margin position (GMP). Concentrations of Porphyromonas gingivalis (Pg) and Aggregatibacter actinomycetemcomitans ( $\mathrm{Aa}$ ) in the subgingival biofilm were also determined. Clinical and microbiological parameters were assessed at baseline $(n=16), 3(n=15), 6(n=15)$ and 12 months $(n=8)$ after treatment. ST was able to promote higher PD reduction compared to NST in deep pockets at 12 months $(p<0.05)$ and in posterior teeth at 6 months $(p<0.05)$. In addition, higher gingival recession was observed in posterior teeth of the ST group at the 6th month $(p<0.05)$. However, ST failed to promoted additional CAL gain in any timepoint $(p>0.05)$. Moreover, microbiological evaluation showed no statistical difference in levels of $\mathrm{Aa}$ and $\mathrm{Pg}$ for both groups at all follow-up periods. Surgical therapy promoted similar clinical benefits to GAgP therapy. Moreover, both therapies failed to reduce $\mathrm{Aa}$ and Pg levels at different follow-up times.
\end{abstract}

Key Words: Aggressive periodontitis, surgical therapy, nonsurgical therapy.

\section{Introduction}

Aggressive periodontitis (AgP) is a complex disease with various factors involved in its pathogenesis. Nevertheless, microbial challenge is a primary etiological factor for the onset and progression of AgP. In addition to genetic and immunologic factors, which were not yet fully established, some microbiological characteristics have been described as determinant and important for the onset and progression of this disease. Among them, the presence and concentration of the pathogen Aggregatibacter actinomycetemcomitans (Aa) has shown to be greater in individuals with generalized aggressive periodontitis (GAgP), besides increasing significantly the risk for the development of the disease as well as the risk for attachment loss (1-3). Other studies still showed that, besides $A a$, there is the presence of a high prevalence of Porphyromonas gingivalis (Pg), Tannerella forsythia (Tf), Campylobacter rectus (Cr), Prevotella intermedia (Pi), Treponema spp, enteric rods and others (4-6).

Despite differences in pathogenesis, biocompatibilization of the root surface is essential for reestablishment of periodontal health. In this context, mechanic therapy is the treatment of choice and has been the target of several studies aiming to reach better treatment protocols that could promote predictable results for AgP control. However, although nonsurgical periodontal therapy appears an option for the treatment of this condition, it is associated with a reduced clinical response (7) and a high percentage of residual sites (8) which reinforces the need for other approaches to reach better results.

Surgical therapy is an alternative that has shown more effective results than nonsurgical therapies regarding chronic periodontitis ( $\mathrm{CrP})$, with significant reduction in probing depth (PD), mainly in deep pockets $(9,10)$. In $13 \mathrm{AgP}$ subjects followed up for 5 years after a surgical therapy plus systemic antimicrobial intake, a significant gain in clinical attachment level (CAL) and a long-term stabilization of results could be seen (11). However, there are no controlled clinical trials comparing surgical to nonsurgical approaches in AgP therapy.

Thus, based on the absence of longitudinal randomized clinical trials that evaluate surgical approaches in $\mathrm{AgP}$, this study aims to compare, through clinical and microbiological parameters, the effect of surgical and nonsurgical periodontal therapies in the treatment of GAgP, with a 12-month follow-up.

\section{Material and Methods}

\section{Study Design}

This study was designed as a randomized controlled clinical trial with a split-mouth experimental design in 
order to determinate microbiological and clinical outcomes of surgical and nonsurgical therapy in the treatment of GAgP. This study was approved by the ethics committee of Piracicaba Dental School of the University of Campinas, under protocol 024/2006. Written informed consent was obtained from the included participants.

\section{Population Screening}

Twenty-one individuals were selected from the postgraduate clinic of Piracicaba Dental School, University of Campinas, southeastern region of Brazil, from March of 2011 to September of 2012. All selected patients received a complete periodontal examination, complete periapical radiographic examination and complete medical and dental anamnesis.

Inclusion criteria were the following: (i) diagnosis of $\mathrm{GAgP}$, according to the American Academy of Periodontology: generalized loss of periodontal attachment affecting at least three teeth other than the first molars and incisors; (ii) presence of at least 20 teeth; (iii) at least 8 teeth in entire mouth presenting PD $\geq 5 \mathrm{~mm}$ with bleeding on probing and at least 2 with $P D \geq 7 \mathrm{~mm}$ (being at least 2 sites $P D \geq 5 \mathrm{~mm}$ and $1 P D \geq 7 \mathrm{~mm}$ in each superior quadrant); $\Xi$ (iv) good general health; and ( $V$ ) $<35$ years of age. Exclusion criteria were (i) periodontal treatment conducted within the last 6 months; (ii) utilization of drugs such as antibiotics or continuous use of anti-inflammatories; (iii) presence of systemic diseases or active infectious diseases (diabetes, cardiovascular, hepatitis etc.); (iv) presence of the habit of smoking; (v) pregnancy or lactation.

\section{Calibration, Randomization and Sample Size Calculation}

For calibration, 2 non-study patients presenting with $\mathrm{GAgP}$ were examined by a designated examiner (CCSC) measuring CAL and PD in all patients twice within 24 $h$, with an interval of $1 \mathrm{~h}$ between examinations. The intraclass correlation was calculated for each parameter, resulting in 90\% for PD and $87 \%$ for CAL. Only superior quadrants were included in this clinical trial. Lower jaws were treated in separate, in the same session, using non-surgical approach. Thus, uppers jaws selected to be treated were allocated to groups according to a computer-generated list, under responsibility of another researcher (RC). This code was not broken until the follow-up was concluded. Sample size calculation was done before the study with a statistical software program (Bioestat release 5.3, Fundação Mamirauá, Belém, PA). This analysis indicated that with 14 patients, the study would have $80 \%$ power to detect a $1 \mathrm{~mm}$ difference in the CAL gain, considering a mean standard deviation of $1.15 \mathrm{~mm}$ (12).

\section{Clinical Treatment \\ Patient Preparation}

After anamnesis and clinical examination to confirm adequacy to study criteria, patients were clarified about $\mathrm{AgP}$ characteristics. Subsequently, they underwent initial periodontal therapy, which included oral hygiene instructions, extraction of hopeless teeth, supragingival scaling, prophylaxis and removal of biofilm retentive factors.

\section{Treatment}

Fourteen days after initial therapy, treatments were conducted in contralateral upper quadrants by a single operator (HFV) in one clinical session, according to the groups:

Nonsurgical Therapy (NST) Group: ultrasonic instrumentation (Cavitron, Dentsply, NY, USA) with specific subgingival access tips (25K FSI ${ }^{\circledR}-\mathrm{SLI}^{\circledR}-10 \mathrm{~S}$, Dentsply), associated with scaling and root planing using Gracey and Mini-five curettes (Hu-Friedy, IL, USA).

Surgical Therapy (ST) Group: intrasulcular incision and elevation of a mucoperiosteal flap to access root surfaces; and then ultrasonic instrumentation with specific subgingival access tips, associated with scaling and root planing using Gracey and Mini-five curettes.

Patients were anesthetized for the completion of treatment. After procedures, quadrants of the ST group received vertical internal mattress sutures with mononylon 5-0. Postoperative instructions and drug prescriptions were given, which included $500 \mathrm{mg}$ sodium dipyrone every 6 $\mathrm{h}$ if they felt pain or discomfort and mouthwash with chlorhexidine gluconate $0.12 \%$ twice daily for 14 days. After 7 days, the sutures were removed.

\section{Clinical Evaluation}

Clinical parameters were assessed in 6 points around each tooth with a North Carolina periodontal probe with 1 mm markers (PCPUNC $15^{\circledR}$ Hu Friedy, IL, USA) as follows: 1) full-mouth plaque index (FMPI), according to Ainamo and Bay (13) and full-mouth bleeding score (FMBS), according to Mühlemann and Son $(14) ; 2)$ probing depth (PD), distance from the bottom of pocket to gingival margin; 3 ) gingival margin position (GMP), distance from the gingival margin to enamel cement junction (CEJ); and 4) clinical attachment level (CAL), distance from the bottom of the pocket to the CEJ. All sites presenting furcation lesions, infra-osseous defects or endo-perio lesions were excluded from examination, avoiding any bias during clinical analysis.

In each evaluation, reinforcement in oral hygiene and professional plaque control were performed.

\section{Microbiological Analysis \\ Biofilm Collection}

Subgingival biofilm samples were obtained from 
randomly selected 2 moderates ( $P D>5-6 \mathrm{~mm}$ ) and 2 deep sites (PD>7 mm), following AAP criteria (Armitage, 1999). Collections were performed in baseline and after 3, 6 and 12 months after treatment.

After careful removal of the supragingival biofilm, relative isolation with cotton rolls and drying, collection was performed. Sterile paper point (\#35) was inserted into the bottom of the periodontal pocket for $30 \mathrm{~s}$. The paper points were placed into sterile tubes containing $300 \mu \mathrm{L}$ 0.5-mM Tris-EDTA.

\section{Microbiologic Analysis}

The presence and concentration of $\mathrm{Pg}$ and $\mathrm{Aa}$ were evaluated by quantitative polymerase chain reaction (qPCR), as previously described in Casarin et al (12). Briefly, DNA was extracted from the subgingival biofilm, using commercial kits (DNA Quiaprep, Qiagen, USA). A qPCR was performed using the hot start reaction mix for PCR (FastStart SybrGreen Master Mix, Roche, RC, USA). The concentration of the DNA used in each run was $10 \mathrm{mg} /$ $\mathrm{mL}$. The amplification profiles were as follows: $95^{\circ} / 10^{\prime}$, $55^{\circ} / 5^{\prime}, 72^{\circ} / 4^{\prime}-40$ cycles for $\mathrm{Pg} ; 95^{\circ} / 10^{\prime}, 55^{\circ} / 5^{\prime}, 72^{\circ} / 3^{\prime}-40$ cycles for Aa. Absolute quantification of target bacteria in clinical samples was performed using Pg (ATCC 33277) and Aa (JP2) as controls. The determination of DNA genome copies in controls was based on the genome size of each bacteria (15). The microbiologic analyses were performed separately for moderate and deep pockets.

\section{Data Management and Statistical Analyses}

The statistical analysis considered the intent to treat. Initially, the values were analyzed for normality by the Shappiro-Wilk test and those variables presenting nonnormal distribution were analyzed with non-parametric tests. On the other hand, parametric ones were used for normally distributed data. The null hypothesis tested was that ST added no clinical or microbiologic benefits to the treatment of GAgP patients compared with NST. To test this hypothesis, a statistical software program was used, and the primary variable was the reduction in $P D$, followed by CAL gain, alteration in GMP and reduction in periodontal pathogens. The homogeneity of groups at baseline was tested using the Student's t test. For clinical parameters, a repeated-measures ANOVA was used to detect intragroup differences in clinical parameters (GMP, $\mathrm{PD}, \mathrm{CAL})$, considering the patient as a statistical unit. The results of GMP, PD and CAL refer strictly to the qualifying sites. When a statistical difference was found, an analysis of the difference was determined using the Tukey method. Differences between groups at each time point was assessed by ANCOVA test, considering baseline values as covariate. The Student's t test was used to determine the differences between groups regarding changes in clinical parameters and the percentage of residual pockets. The Friedman test was used to detect intragroup differences, and the KruskallWallis test was used for intergroup analysis of full-mouth plaque and bleeding indices in all periods. The experimental level of significance was determined to be $5 \%$.

\section{Results}

Figure 1 presents the timeline of patient's follow-up. Figure 2 illustrates the flowchart of the study. During patients' recruitment, 21 individuals were selected as possible participants of the study. After initial exam, 5 of them were excluded (two diagnosed with localized $\mathrm{AgP}$, two refused to participate and one smoker). Then, 16 patients filled the inclusion criteria and were included in the study. One patient was excluded for not accomplishing the 3-month follow-up. At the 12-month follow-up, 7 patients were also excluded-two due to antibiotics intake, one due to pregnancy and four moved to another city. Although a final sample of 8 was below previously indicate, a posthoc power analysis indicated a power value of $96 \%$ for PD reduction and 75\% of CAL gain at 12 months in deep pockets, allowing a quite reliable analysis.

Table 1 shows patients' characteristics at baseline. There was no difference between groups regarding oral hygiene status, and there was no difference in clinical parameters ( $p>0.05)$.

Data about plaque and bleeding scores are presented in Table 2. Considering bleeding on probing (BoP), there was a significant reduction for all pockets from baseline to 3 months, with no differences between groups. For moderate and deep pockets, there was a significant reduction at $3 \mathrm{rd}$ month, $(p<0.05)$ in both groups similarly $(p>0.05)$. However, in deep pockets, a trend to increase was observed in both groups, and no difference to baseline or 3rd month being observed at 6 th and 12 th months. There were no statistically significant changes in plaque index (PI), considering different times and different groups.

Data from clinical parameters are described in Table 3. Considering all pockets, both treatments promoted significant reduction in PD and CAL gain $(p<0.05)$, with no differences between groups ( $p>0.05)$. However, although both treatments promoted significant increase in GMP $(p<0.05)$, the ST group presented, at the 6th month, higher gingival recession than the NST group ( $p<0.05)$. At the 12 th month, no differences were observed anymore ( $p>0.05)$.

Concerning moderate pockets, both therapies promoted significant changes (reduction in PD, gain of CAL and increase in GMP) during follow-up. Moreover, changes in $P D, C A L$ and GMP were similar between groups ( $p>0.05)$. However, in deep pockets, the ST group presented at the 12th month of follow-up a statistically significant 
difference in PD $(5.9 \pm 1.2 \mathrm{~mm}$ and $4.8 \pm 0.6 \mathrm{~mm}$ in NST and ST, respectively, $\mathrm{p}=0.047)$. Moreover, ST promoted a higher PD reduction $(2.9 \pm 0.7 \mathrm{~mm})$ than NST $(1.5 \pm 1.1 \mathrm{~mm})$, although a borderline $p$-value was achieved $(p=0.0572)$. CAL and GMP for deep pockets did not present significant differences between groups.

Considering only anterior teeth, all clinical parameters similarly changed during the 12th follow-up $(p<0.05)$ in the NST and ST groups, with no statistical difference between them ( $p>0.05$ ). Differently, in regard to posterior teeth, the ST group presented a significantly lower PD mean at the 6th month $(4.1 \pm 1.3 \mathrm{~mm})$ when compared to the NST group $(4.8 \pm 0.8 \mathrm{~mm})$, with $p=0.03$. Additionally, at 12 months, PD values in NST group did not differ anymore to baseline value ( $p>0.05)$, although it was not different to $3 \mathrm{rd}$ and 6th month evaluation, indicating a trend in increase of PD. Moreover, the ST group also presented a higher gingival recession in posterior teeth than NST at the 6th month (NST: $-0.2 \pm 0.2 \mathrm{~mm}, \mathrm{ST}:-0.7 \pm 1.2 \mathrm{~mm} ; \mathrm{p}=0.05$ ).

Contradictorily, although significant clinical changes occurred, microbiological analysis failed to demonstrate significant changes in $\mathrm{Aa}$ and $\mathrm{Pg}$ levels between groups or periods of evaluation (Fig. $3 ; p>0.05$ ), in spite of pocket strata (moderate or deep pockets - Fig. $4 ; p>0.05$ ) or teeth location (anterior or posterior - Fig. $5 ; p>0.05$ ).

\section{Discussion}

The present study clinically and microbiologically evaluated surgical and nonsurgical periodontal therapy in the treatment of GAgP patients. There remains a challenge for clinicians in the treatment of $\mathrm{AgP}$, due to its rapid progression and the paradigm of worse response. Several studies have been conducted in order to achieve better results, but there are few studies in the literature that support surgical therapy as an effective alternative in treatment of this condition. The findings of the present study demonstrated that the surgical approach promoted additional probing depth reduction in deep pockets (1.1 $\mathrm{mm}$ at 12-month follow-up) and posterior teeth $(0.7 \mathrm{~mm}$ at 6-month follow-up), although it also promoted higher gingival recession in all pockets $(0.3 \mathrm{~mm})$ and posterior teeth $(0.5 \mathrm{~mm})$.

Systematic reviews and meta-analyses have shown that reductions in probing depth are greater in surgically treated sites, particularly in deep pockets, in patients with chronic periodontitis $(9,10)$. Nevertheless, few studies have addressed surgical therapy in AgP, but these often report promising results. In a small sample size trial, Christersson

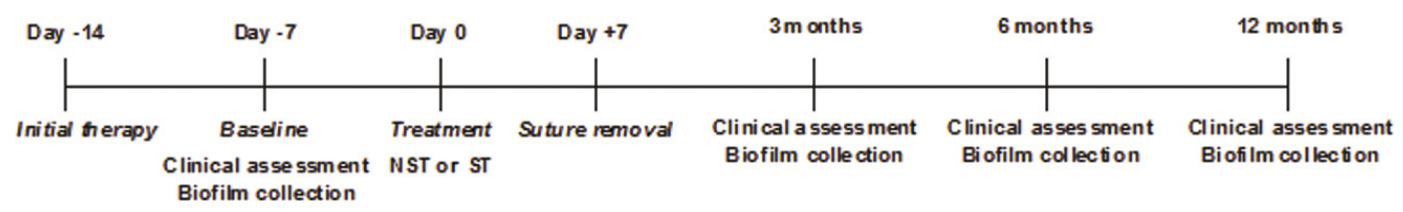

Figure 1. Timeline of patient's follow-up.

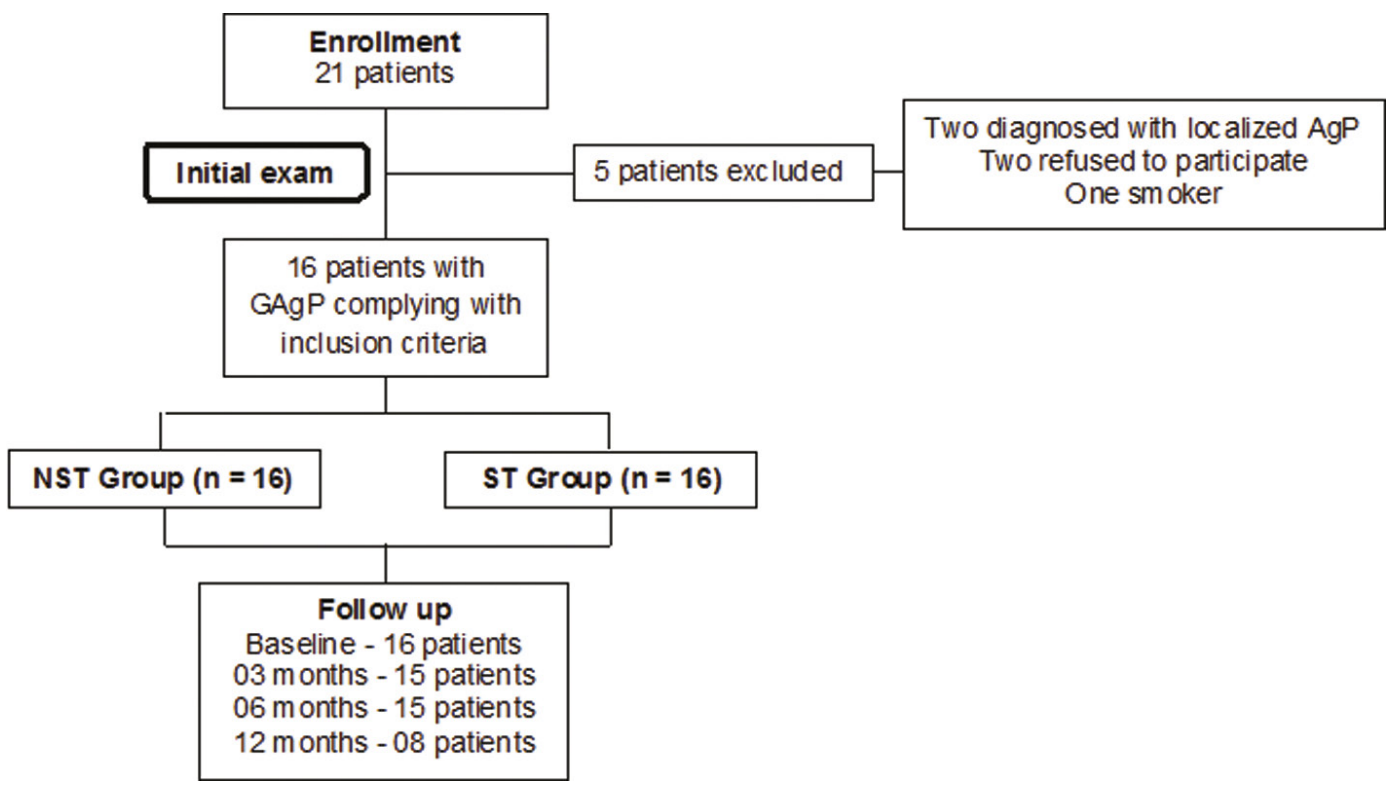


et al. (16), treating deep sites of localized AgP patients, showed no significant changes in PD for the scaled and root

Table 1. Patient's characteristics at baseline

\begin{tabular}{lcc}
\hline Characteristics & NST & ST \\
\hline Age (years) (mean \pm SD) & $27.2 \pm 5.0$ & \\
Females (\%) & 93.7 & \\
PI (mean \pm SD) & 46.2 & 38.5 \\
BoP (mean \pm SD) & 92.3 & 92.3 \\
PD (mean \pm SD) & $6.2 \pm 0.7$ & $6.2 \pm 1.3$ \\
CAL (mean \pm SD) & $6.4 \pm 0.8$ & $6.4 \pm 1.3$ \\
GMP (mean \pm SD) & $0.2 \pm 0.4$ & $0.5 \pm 0.8$ \\
\hline
\end{tabular}

At baseline, no significant differences were observed in any characteristic analyzed (ANOVA/Tukey).

Table 2. Plaque and Bleeding on Probing indexes (\% of positive sites) at baseline, 3, 6, and 12 months at both groups

\begin{tabular}{|c|c|c|c|c|c|c|c|}
\hline & & \multicolumn{2}{|c|}{ All pockets } & \multicolumn{2}{|c|}{ Moderate Pockets } & \multicolumn{2}{|c|}{ Deep Pockets } \\
\hline & & NST & ST & NST & ST & NST & ST \\
\hline \multirow{4}{*}{$\mathrm{BoP}$} & Baseline $(\mathrm{n}=16)$ & $92.3 \mathrm{Aa}$ & $92.3 \mathrm{Aa}$ & 92.3 Аa & $84.6 \mathrm{Aa}$ & $92.3 \mathrm{Aa}$ & $92.3 \mathrm{Aa}$ \\
\hline & 3 months $(n=15)$ & $53.8 \mathrm{Ab}$ & 46.2 Ab & $23.1 \mathrm{Ab}$ & $15.4 \mathrm{Ab}$ & $30.8 \mathrm{Ab}$ & $38.5 \mathrm{Ab}$ \\
\hline & 6 months $(n=15)$ & $61.5 \mathrm{Ab}$ & $61.5 \mathrm{Ab}$ & 53.8 Aab & 30.8 Aab & 53.8 Aab & 53.8 Aab \\
\hline & 12 months $(\mathrm{n}=8)$ & $66.7 \mathrm{Ab}$ & 66.7 Aab & $50.0 \mathrm{Ab}$ & $16.7 \mathrm{Ab}$ & 66.7 Aab & 66.7 Aab \\
\hline \multirow{4}{*}{ PI } & Baseline $(\mathrm{n}=16)$ & 46.2 Aa & $38.5 \mathrm{Aa}$ & $53.8 \mathrm{Aa}$ & $30.8 \mathrm{Aa}$ & 46.2 Аа & $38.5 \mathrm{Aa}$ \\
\hline & 3 months $(n=15)$ & $46.2 \mathrm{Aa}$ & 46.2 Аа & 46.2 Аа & 46.2 Аа & 46.2 Аа & 46.2 Аа \\
\hline & 6 months $(n=15)$ & $53.8 \mathrm{Aa}$ & 46.2 Aa & $38.5 \mathrm{Aa}$ & $38.5 \mathrm{Aa}$ & 46.2 Аа & $53.8 \mathrm{Aa}$ \\
\hline & 12 months $(\mathrm{n}=8)$ & $50.0 \mathrm{Aa}$ & $37.5 \mathrm{Aa}$ & $37.5 \mathrm{Aa}$ & $37.5 \mathrm{Aa}$ & $25.0 \mathrm{Aa}$ & $37.5 \mathrm{Aa}$ \\
\hline
\end{tabular}

Distinct letters (lower case within time and capital between groups) indicate statistically significant difference by Chi-Square test $(\mathrm{p}<0.05)$. planed groups. On the other hand, for the surgically treated group, PD measures decreased approximately $2.6 \mathrm{~mm}$ after 16 weeks. Surgical therapy has also demonstrated to be an effective approach with regard to long-term periodontal stability. Wennstrom et al (17), in long-term follow-up, also demonstrated a great reduction of probing depth between baseline and 6 months in sites treated with open-flap scaling and root planing, with minor variation between 2- and 5-year follow-ups, in patients with localized AgP. Considering GAgP patients, a prospective case series (11) treated sites with PD greater or equal to $6 \mathrm{~mm}$ with surgical access associated with systemic amoxicillin/metronidazole intake. At the 3-month evaluation, the gain of CAL was 2.23 $\mathrm{mm}$, reaching $2.57 \mathrm{~mm}$ at the 5-year follow-up. Compared to results achieved in the present study, in which the CAL gain was about $2.5 \mathrm{~mm}$ at the 1-year follow-up, it appears that surgical therapy alone could also achieve promising results for $\mathrm{GAgP}$ treatment.

A recent review indicated that adjunctive use of antimicrobials for nonsurgical therapy promotes statistically significant improvements in CAL gain and PD reduction $(18,19)$. Several studies have evidenced additional benefits of antimicrobial therapies in $\operatorname{AgP}(11,12,20-22)$, even though it has not yet been established which is the most appropriate antimicrobial protocol. Some clinical trials $(12,20,21)$ evaluated the association of amoxicillin and metronidazole with a nonsurgical approach and found a reduction in PD ranging between 3.1 and 4.27
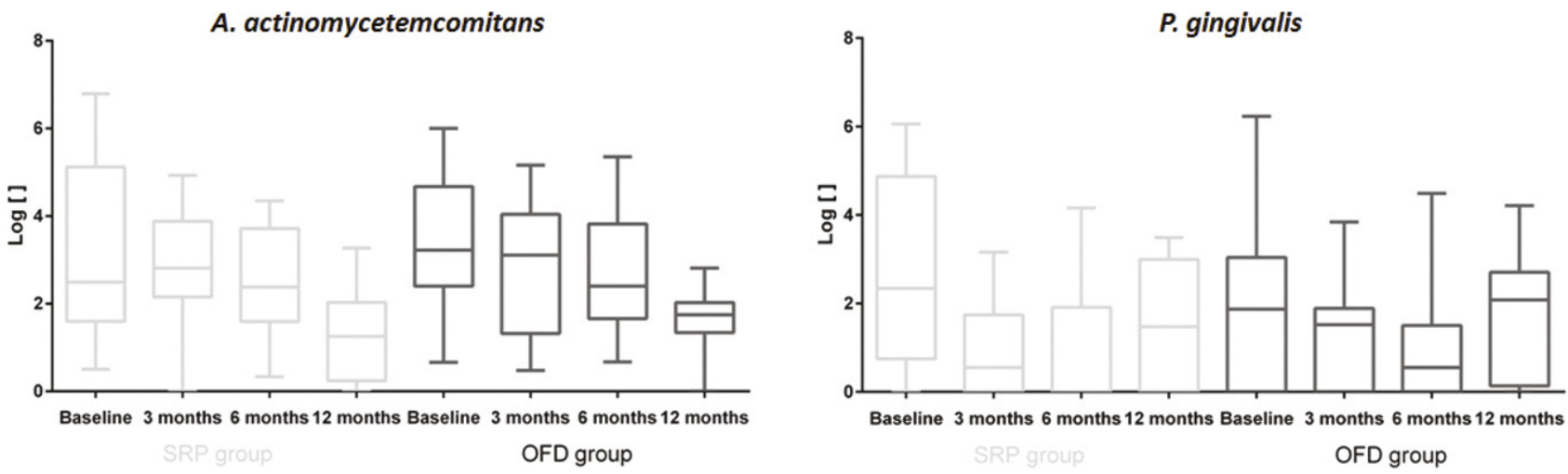

Figure 3. A. actinomycetemcomitans (left) and P. gingivalis (right) amounts (log[ ]) in each group in all pockets during 12-months of follow-up. No difference between groups (Friedman and Wilcoxon's tests, $\mathrm{p}>0.05$ ) 
$\mathrm{mm}$ and CAL gain ranging between 2.3 and $3.43 \mathrm{~mm}$ in deep pockets. Those data, when compared to the ones achieved in the present study $(2.9 \mathrm{~mm}$ of PD reduction and $2.5 \mathrm{~mm}$ of CAL gain in deep pockets), evidenced possible additional benefits of systemic antibiotics when associated with nonsurgical therapy. Nonetheless, there is no controlled clinical trial that presents clear answers about benefits achieved, particularly in association with surgical therapy.

Moreover, one of the main goals of periodontal therapy is to arrest the progression of the disease. It was observed that patients subjected to nonsurgical therapy exhibited signs of disease progression in the long term (23). Furthermore, Badersten et al. (23) demonstrated that sites with an increase in PD $>1 \mathrm{~mm}$ showed an increase of about $78 \%$ of predictive value for attachment loss. The outcome of the present study demonstrated a stability of CAL during all monitoring periods; however, sites treated with nonsurgical instrumentation showed a tendency of recurrence in deep pockets and posterior teeth, with additional CAL loss and increase in PD over time. This result could be attributed to a greater difficulty in plaque control and root instrumentation, especially in those critical areas, such as deep sites and furcation. The surgical approach seems to be more effective to access the root surfaces, promoting a more thorough debridement and additional benefits, especially in areas with difficult access, such as

Table 3. Clinical parameters $\left(\mathrm{mm}_{ \pm} \mathrm{sd}\right)$ of NST and ST groups, regarding all, moderate and deep pockets, as well as in anterior and posterior teeth, at baseline, 3, 6 and 12 months of follow-up

\begin{tabular}{|c|c|c|c|c|c|c|c|c|}
\hline & & & Baseline $(n=16)$ & $\begin{array}{l}3 \text { months } \\
(\mathrm{n}=15)\end{array}$ & $\begin{array}{l}6 \text { months } \\
(\mathrm{n}=15)\end{array}$ & $\begin{array}{l}\Delta 0-6 \\
\text { months }\end{array}$ & $\begin{array}{l}12 \text { months } \\
(\mathrm{n}=8)\end{array}$ & $\begin{array}{l}\Delta 0-12 \\
\text { months }\end{array}$ \\
\hline \multirow{9}{*}{$\begin{array}{l}\text { All } \\
\text { pockets }\end{array}$} & & NST & $6.2 \pm 0.7$ & $4.4 \pm 0.7 \dagger$ & $4.4 \pm 0.8 \dagger$ & $1.8 \pm 1.0$ & $4.5 \pm 0.6 t$ & $1.7 \pm 1.1$ \\
\hline & & ST & $6.2 \pm 1.3$ & $4.1 \pm 0.7 \dagger$ & $4.2 \pm 0.9 \dagger$ & $2.0 \pm 1.1$ & $4.2 \pm 0.7 \dagger$ & $2.0 \pm 1.1$ \\
\hline & PD & $\begin{array}{c}\mathrm{p} \\
\text { value }\end{array}$ & - & $\begin{array}{c}\mathrm{p}=0.28 \\
\text { (ANCOVA) }\end{array}$ & $\begin{array}{c}\mathrm{p}=0.42 \\
(\text { ANCOVA) }\end{array}$ & $\begin{array}{l}\mathrm{p}=0.26 \text { (paired } \\
\text { Student's t test) }\end{array}$ & $\begin{array}{c}\mathrm{p}=0.39 \\
\text { (ANCOVA) }\end{array}$ & $\begin{array}{c}\mathrm{p}=0.93 \\
0.26 \text { (paired } \\
\text { Student's t test) }\end{array}$ \\
\hline & \multirow[b]{3}{*}{ CAL } & NST & $6.4 \pm 0.8$ & $4.9 \pm 0.8 \dagger$ & $5.0 \pm 1.0 \dagger$ & $1.4 \pm 0.9$ & $5.2 \pm 0.8 \dagger$ & $1.2 \pm 1.0$ \\
\hline & & ST & $6.7 \pm 1.3$ & $5.2 \pm 1.3+$ & $5.4 \pm 1.6 \dagger$ & $1.3 \pm 1.0$ & $5.1 \pm 1.6 t$ & $1.1 \pm 1.2$ \\
\hline & & $\begin{array}{c}\mathrm{p} \\
\text { value }\end{array}$ & - & $\begin{array}{c}\mathrm{p}=0.61 \\
\text { (ANCOVA) }\end{array}$ & $\begin{array}{c}p=0.59 \\
\text { (ANCOVA) }\end{array}$ & $\begin{array}{l}\mathrm{p}=0.42 \text { (paired } \\
\text { Student's t test) }\end{array}$ & $\begin{array}{c}\mathrm{p}=0.97 \\
\text { (ANCOVA) }\end{array}$ & $\begin{array}{l}\mathrm{p}=0.91 \text { (paired } \\
\text { Student's t test) }\end{array}$ \\
\hline & \multirow[b]{3}{*}{ GMP } & NST & $0.2 \pm 0.4$ & $0.5 \pm 1.1$ & $0.6 \pm 0.6 t$ & $-0.4 \pm 0.5$ & $0.7 \pm 0.5 t$ & $-0.5 \pm 0.4$ \\
\hline & & ST & $0.5 \pm 0.8$ & $1.1 \pm 1.2 \dagger$ & $1.2 \pm 1.3 \dagger$ & $-0.7 \pm 0.7$ & $1.0 \pm 1.2 \dagger$ & $-0.5 \pm 0.5$ \\
\hline & & $\begin{array}{c}\mathrm{p} \\
\text { value }\end{array}$ & - & $\begin{array}{c}\mathrm{p}=0.3 \\
\text { (ANCOVA) }\end{array}$ & $\begin{array}{c}p=0.2 \\
\text { (ANCOVA) }\end{array}$ & $\begin{array}{l}\mathrm{p}=0.03^{*} \text { (paired } \\
\text { Student's } \mathrm{t} \text { test) }\end{array}$ & $\begin{array}{c}\mathrm{p}=0.57 \\
(\text { ANCOVA) }\end{array}$ & $\begin{array}{l}\mathrm{p}=0.6 \text { (paired } \\
\text { Student's } \mathrm{t} \text { test) }\end{array}$ \\
\hline \multirow{9}{*}{$\begin{array}{l}\text { Moderate } \\
\text { pockets }\end{array}$} & \multirow[b]{3}{*}{ PD } & NST & $5.3 \pm 0.4$ & $3.9 \pm 0.7 \dagger$ & $3.9 \pm 0.9 t$ & $1.4 \pm 0.9$ & $4.1 \pm 1.3+$ & $1.3 \pm 1.4$ \\
\hline & & ST & $5.2 \pm 0.4$ & $3.8 \pm 0.6+$ & $3.8 \pm 0.9 \dagger$ & $1.5 \pm 0.9$ & $4.2 \pm 0.9+$ & $1.0 \pm 1.0$ \\
\hline & & $\begin{array}{c}\mathrm{p} \\
\text { value }\end{array}$ & - & $\begin{array}{c}\mathrm{p}=0.71 \\
(\text { ANCOVA) }\end{array}$ & $\begin{array}{c}p=0.68 \\
(\text { ANCOVA) }\end{array}$ & $\begin{array}{l}\mathrm{p}=0.79 \text { (paired } \\
\text { Student's t test) }\end{array}$ & $\begin{array}{c}\mathrm{p}=0.98 \\
(\text { ANCOVA) }\end{array}$ & $\begin{array}{l}p=0.33 \text { (paired } \\
\text { Student's t test) }\end{array}$ \\
\hline & \multirow[b]{3}{*}{ CAL } & NST & $5.5 \pm 0.6$ & $4.5 \pm 0.8 \dagger$ & $4.5 \pm 0.9 \dagger$ & $1.0 \pm 0.8$ & $4.8 \pm 1.1 \dagger$ & $0.7 \pm 1.3$ \\
\hline & & ST & $5.5 \pm 0.5$ & $4.5 \pm 0.7 \dagger$ & $4.6 \pm 1.2 \dagger$ & $0.9 \pm 1.0$ & $4.6 \pm 0.9+$ & $0.9 \pm 1.0$ \\
\hline & & $\begin{array}{c}\mathrm{p} \\
\text { value }\end{array}$ & - & $\begin{array}{c}\mathrm{p}=0.95 \\
\text { (ANCOVA) }\end{array}$ & $\begin{array}{c}p=0.69 \\
(\text { ANCOVA) }\end{array}$ & $\begin{array}{l}\mathrm{p}=0.62 \text { (paired } \\
\text { Student's } \mathrm{t} \text { test) }\end{array}$ & $\begin{array}{c}p=0.73 \\
(\text { ANCOVA) }\end{array}$ & $\begin{array}{l}\mathrm{p}=0.71 \text { (paired } \\
\text { Student's } \mathrm{t} \text { test) }\end{array}$ \\
\hline & \multirow{3}{*}{ GMP } & NST & $0.3 \pm 0.5$ & $0.5 \pm 0.7$ & $0.6 \pm 0.8$ & $-0.3 \pm 0.6$ & $0.7 \pm 0.7 \dagger$ & $-0.4 \pm 0.4$ \\
\hline & & ST & $0.3 \pm 0.6$ & $0.7 \pm 0.5 t$ & $0.9 \pm 0.8 \dagger$ & $-0.6 \pm 0.5$ & $0.4 \pm 0.5$ & $-0.1 \pm 0.3$ \\
\hline & & $\begin{array}{c}\mathrm{p} \\
\text { value }\end{array}$ & - & $\begin{array}{c}\mathrm{p}=0.62 \\
\text { (ANCOVA) }\end{array}$ & $\begin{array}{c}\mathrm{p}=0.31 \\
\text { (ANCOVA) }\end{array}$ & $\begin{array}{l}\mathrm{p}=0.14 \text { (paired } \\
\text { Student's t test) }\end{array}$ & $\begin{array}{c}\mathrm{p}=0.81 \\
\text { (ANCOVA) }\end{array}$ & $\begin{array}{l}\mathrm{p}=0.77 \text { (paired } \\
\text { Student's } \mathrm{t} \text { test) }\end{array}$ \\
\hline
\end{tabular}


deep sites and furcation areas (24). This could result in better calculus and biofilm removal on scaled areas and, consequently, an optimized microbiota reduction. However, the microbiological findings of this study failed to find

\begin{tabular}{|c|c|c|c|c|c|c|c|c|}
\hline & & NST & $7.6 \pm 0.5$ & $5.2 \pm 0.9 \dagger$ & $5.2 \pm 1.1 \dagger$ & $2.4 \pm 1.5$ & $5.9 \pm 1.2 \dagger$ & $1.5 \pm 1.1$ \\
\hline & & ST & $7.7 \pm 0.8$ & $5.2 \pm 1.1 \dagger$ & $4.7 \pm 1.3 \dagger$ & $3.0 \pm 1.4$ & $4.8 \pm 0.6+$ & $2.9 \pm 0.7$ \\
\hline & PD & $\begin{array}{c}\mathrm{p} \\
\text { value }\end{array}$ & - & $\begin{array}{c}\mathrm{p}=0.96 \\
\text { (ANCOVA) }\end{array}$ & $\begin{array}{c}\mathrm{p}=0.31 \\
\text { (ANCOVA) }\end{array}$ & $\begin{array}{l}\mathrm{p}=0.26 \text { (paired } \\
\text { Student's t test) }\end{array}$ & $\begin{array}{l}\mathrm{p}=0.047^{*} \\
\text { (ANCOVA) }\end{array}$ & $\begin{array}{l}\mathrm{p}=0.06 \text { (paired } \\
\text { Student's t test) }\end{array}$ \\
\hline & & NST & $7.8 \pm 0.6$ & $5.8 \pm 0.8 \dagger$ & $6.0 \pm 1.2 \dagger$ & $1.8 \pm 1.5$ & $6.5 \pm 1.4 \dagger$ & $1.3 \pm 1.1$ \\
\hline & & ST & $7.9 \pm 1.2$ & $6.1 \pm 1.8 \dagger$ & $5.6 \pm 2.1 \dagger$ & $2.3 \pm 1.7$ & $5.4 \pm 1.2 \dagger$ & $2.5 \pm 1.2$ \\
\hline pockets & CAL & $\begin{array}{c}\mathrm{p} \\
\text { value }\end{array}$ & - & $\begin{array}{c}\mathrm{p}=0.71 \\
\text { (ANCOVA) }\end{array}$ & $\begin{array}{c}p=0.49 \\
(\text { ANCOVA) }\end{array}$ & $\begin{array}{l}\mathrm{p}=0.29 \text { (paired } \\
\text { Student's t test) }\end{array}$ & $\begin{array}{c}p=0.31 \\
\text { (ANCOVA) }\end{array}$ & $\begin{array}{l}\mathrm{p}=0.15 \text { (paired } \\
\text { Student's t test) }\end{array}$ \\
\hline & & NST & $0.2 \pm 0.5$ & $0.6 \pm 0.7$ & $0.8 \pm 0.7 \dagger$ & $-0.5 \pm 0.7$ & $0.7 \pm 0.7+$ & $-0.5 \pm 0.5$ \\
\hline & & ST & $0.3 \pm 0.8$ & $0.9 \pm 1.4 \dagger$ & $0.9 \pm 1.3 \dagger$ & $-0.6 \pm 1.0$ & $0.7 \pm 0.9 \dagger$ & $-0.4 \pm 1.0$ \\
\hline & GMP & $\begin{array}{c}\mathrm{p} \\
\text { value }\end{array}$ & - & $\begin{array}{c}\mathrm{p}=0.65 \\
(\text { ANCOVA) }\end{array}$ & $\begin{array}{c}p=0.78 \\
(\text { ANCOVA) }\end{array}$ & $\begin{array}{l}\mathrm{p}=0.63 \text { (paired } \\
\text { Student's t test) }\end{array}$ & $\begin{array}{c}\mathrm{p}=0.82 \\
\text { (ANCOVA) }\end{array}$ & $\begin{array}{l}\mathrm{p}=0.53 \text { (paired } \\
\text { Student's t test) }\end{array}$ \\
\hline & & NST & $6.5 \pm 1.2$ & $4.3 \pm 0.8 \dagger$ & $4.3 \pm 1.0 \dagger$ & $2.2 \pm 1.3$ & $4.0 \pm 1.0 \dagger$ & $2.5 \pm 1.1$ \\
\hline & & ST & $6.3 \pm 1.1$ & $4.2 \pm 0.7 \dagger$ & $4.2 \pm 0.7 \dagger$ & $2.1 \pm 1.0$ & $4.4 \pm 1.3 \dagger$ & $1.9 \pm 1.8$ \\
\hline & $1 D$ & $\begin{array}{c}\mathrm{p} \\
\text { value }\end{array}$ & - & $\begin{array}{c}\mathrm{p}=0.83 \\
\text { (ANCOVA) }\end{array}$ & $\begin{array}{c}\mathrm{p}=0.58 \\
\text { (ANCOVA) }\end{array}$ & $\begin{array}{l}\mathrm{p}=0.74 \text { (paired } \\
\text { Student's t test) }\end{array}$ & $\begin{array}{c}\mathrm{p}=0.87 \\
\text { (ANCOVA) }\end{array}$ & $\begin{array}{l}\mathrm{p}=0.24 \text { (paired } \\
\text { Student's t test) }\end{array}$ \\
\hline & & NST & $6.8 \pm 1.3$ & $5.1 \pm 1.1 \dagger$ & $5.3 \pm 1.5 t$ & $1.5 \pm 1.4$ & $5.1 \pm 1.7+$ & $1.7 \pm 0.9$ \\
\hline teeth & & ST & $6.8 \pm 1.1$ & $5.1 \pm 0.9+$ & $5.3 \pm 1.2 \dagger$ & $1.5 \pm 0.9$ & $4.8 \pm 1.5 t$ & $2.0 \pm 1.9$ \\
\hline & CAL & $\begin{array}{c}\mathrm{p} \\
\text { value }\end{array}$ & - & $\begin{array}{c}\mathrm{p}=0.94 \\
(\text { ANCOVA) }\end{array}$ & $\begin{array}{c}p=0.91 \\
(\text { ANCOVA) }\end{array}$ & $\begin{array}{l}\mathrm{p}=0.78 \text { (paired } \\
\text { Student's t test) }\end{array}$ & $\begin{array}{c}p=0.97 \\
\text { (ANCOVA) }\end{array}$ & $\begin{array}{l}\mathrm{p}=0.76 \text { (paired } \\
\text { Student's t test) }\end{array}$ \\
\hline & & NST & $0.3 \pm 0.8$ & $0.8 \pm 1.1 \dagger$ & $1.0 \pm 1.3 t$ & $-0.7 \pm 0.9$ & $1.1 \pm 1.4 \dagger$ & $-0.8 \pm 0.5$ \\
\hline & & ST & $0.5 \pm 0.9$ & $0.9 \pm 0.9 t$ & $1.1 \pm 1.1 \dagger$ & $-0.6 \pm 0.8$ & $0.4 \pm 0.8$ & $0.1 \pm 0.5$ \\
\hline & GMP & $\begin{array}{c}\mathrm{p} \\
\text { value }\end{array}$ & - & $\begin{array}{c}\mathrm{p}=0.97 \\
\text { (ANCOVA) }\end{array}$ & $\begin{array}{c}\mathrm{p}=0.9 \\
\text { (ANCOVA) }\end{array}$ & $\begin{array}{l}\mathrm{p}=0.79 \text { (paired } \\
\text { Student's t test) }\end{array}$ & $\begin{array}{c}\mathrm{p}=0.11 \\
(\text { ANCOVA) }\end{array}$ & $\begin{array}{l}\mathrm{p}=0.07 \text { (paired } \\
\text { Student's t test) }\end{array}$ \\
\hline & & NST & $6.3 \pm 0.9$ & $4.8 \pm 0.9 \dagger$ & $4.8 \pm 0.8 \dagger$ & $1.5 \pm 0.8$ & $5.5 \pm 1.3$ & $0.8 \pm 1.4$ \\
\hline & PD & ST & $6.5 \pm 1.2$ & $4.3 \pm 0.9 t$ & $4.1 \pm 1.3 \dagger$ & $2.4 \pm 1.9$ & $4.6 \pm 1.0 \dagger$ & $1.9 \pm 1.9$ \\
\hline & & $\begin{array}{c}\mathrm{p} \\
\text { value }\end{array}$ & & $\begin{array}{c}\mathrm{p}=0.18 \\
(\text { ANCOVA) }\end{array}$ & $\begin{array}{c}\mathrm{p}=0.03^{*} \\
\text { (ANCOVA) }\end{array}$ & $\begin{array}{l}\mathrm{p}=0.08 \text { (paired } \\
\text { Student's t test) }\end{array}$ & $\begin{array}{c}p=0.20 \\
\text { (ANCOVA) }\end{array}$ & $\begin{array}{l}\mathrm{p}=0.10 \text { (paired } \\
\text { Student's t test) }\end{array}$ \\
\hline Posterior & & NST & $6.5 \pm 0.9$ & $5.2 \pm 1.1 \dagger$ & $5.2 \pm 0.9 \dagger$ & $1.3 \pm 0.8$ & $5.9 \pm 1.2+$ & $0.6 \pm 1.4$ \\
\hline teeth & & ST & $6.5 \pm 1.2$ & $4.9 \pm 1.0 \dagger$ & $4.9 \pm 2.1 \dagger$ & $1.6 \pm 2.5$ & $5.2 \pm 1.3+$ & $1.3 \pm 1.3$ \\
\hline & CAL & $\begin{array}{c}\mathrm{p} \\
\text { value }\end{array}$ & - & $\begin{array}{c}\mathrm{p}=0.87 \\
\text { (ANCOVA) }\end{array}$ & $\begin{array}{c}\mathrm{p}=0.6 \\
\text { (ANCOVA) }\end{array}$ & $\begin{array}{l}\mathrm{p}=0.64 \text { (paired } \\
\text { Student's t test) }\end{array}$ & $\begin{array}{c}p=0.89 \\
\text { (ANCOVA) }\end{array}$ & $\begin{array}{l}\mathrm{p}=0.68 \text { (paired } \\
\text { Student's t test) }\end{array}$ \\
\hline & & NST & $0.2 \pm 0.4$ & $0.3 \pm 0.5$ & $0.4 \pm 0.5 \dagger$ & $-0.2 \pm 0.2$ & $0.4 \pm 0.5 t$ & $-0.2 \pm 0.3$ \\
\hline & GMP & ST & $0.0 \pm 0.0$ & $0.6 \pm 0.8 \dagger$ & $0.7 \pm 1.2 \dagger$ & $-0.7 \pm 1.2$ & $0.5 \pm 0.7 \dagger$ & $-0.5 \pm 0.7$ \\
\hline & & $\begin{array}{c}\mathrm{p} \\
\text { value }\end{array}$ & - & $\begin{array}{c}\mathrm{p}=0.09 \\
\text { (ANCOVA) }\end{array}$ & $\begin{array}{c}\mathrm{p}=0.12 \\
(\mathrm{ANCOVA})\end{array}$ & $\begin{array}{l}\mathrm{p}=0.05^{*} \text { (paired } \\
\text { Student's t test) }\end{array}$ & $\begin{array}{c}p=0.2 \\
(\text { ANCOVA) }\end{array}$ & $\begin{array}{l}\mathrm{p}=0.06 \text { (paired } \\
\text { Student's t test) }\end{array}$ \\
\hline
\end{tabular}

*indicate significant difference between groups. + indicate significant difference to baseline; SD - Standard deviation; PD - Probing Depth; CAL - Clinical Attachment Level; GMP - Gingival Margin Position 
significant differences between groups.

Both surgical and nonsurgical approaches failed to promote significant reduction in the amounts of $\mathrm{Pg}$ and Aa. The presence of these pathogens in the subgingival environment significantly increases the risk of disease development as well as the risk of attachment loss $(1,2)$.
A substantial suppression of Aa could not be achieved by scaling and root planing alone in some studies; however, a surgical approach was able to suppress $A a$ in 55.5\% of pockets after 16 months (16) when antimicrobial therapy was prescribed adjunctively. Another studies achieved significantly lower counts of Aa in scaling and root
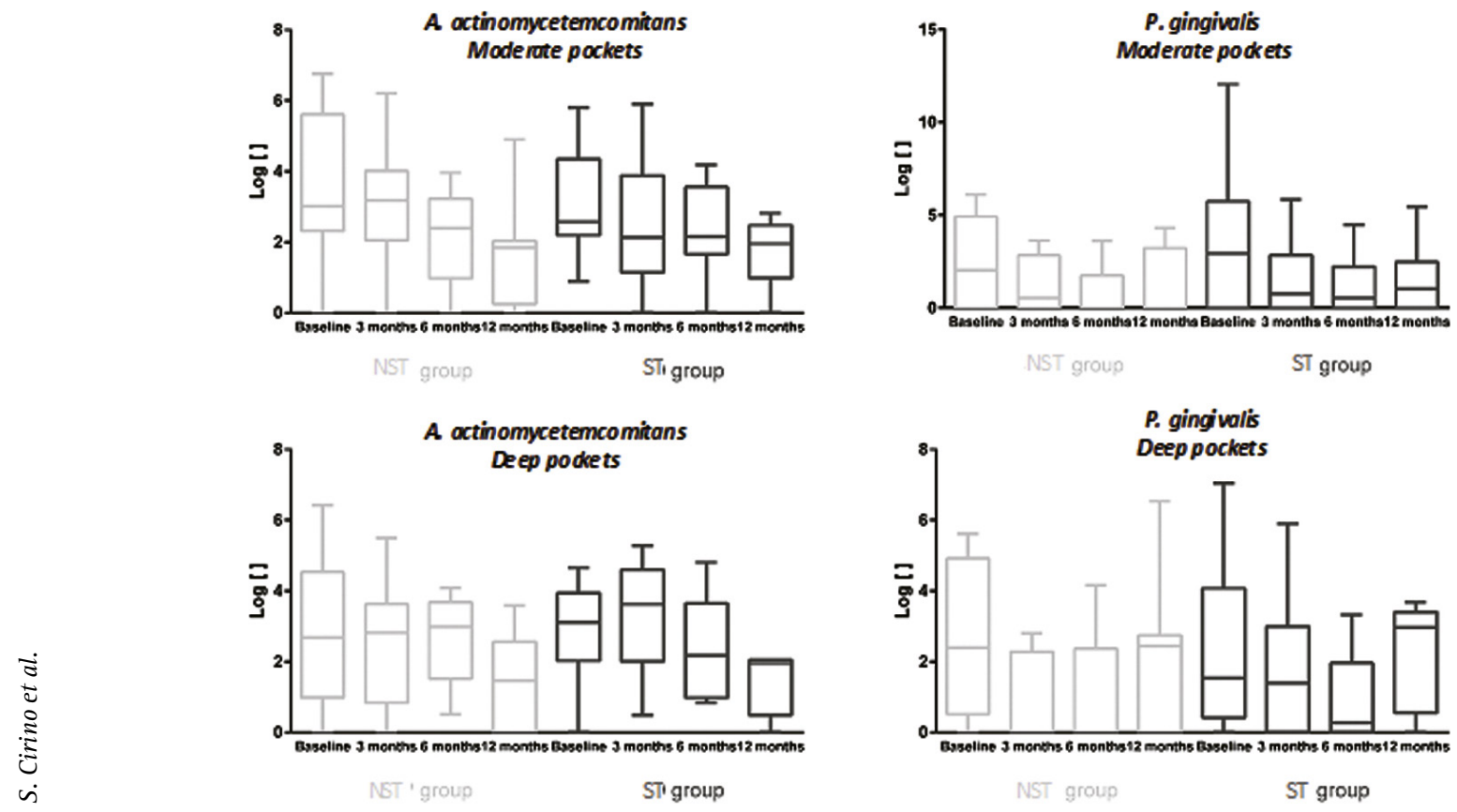

Figure 4. A. actinomycetemcomitans (left) and P. gingivalis (right) amounts (log[ ]) in each group in moderate and deep pockets during 12 -months of follow-up. No difference between groups (Friedman and Wilcoxon's tests, $p>0.05$ )
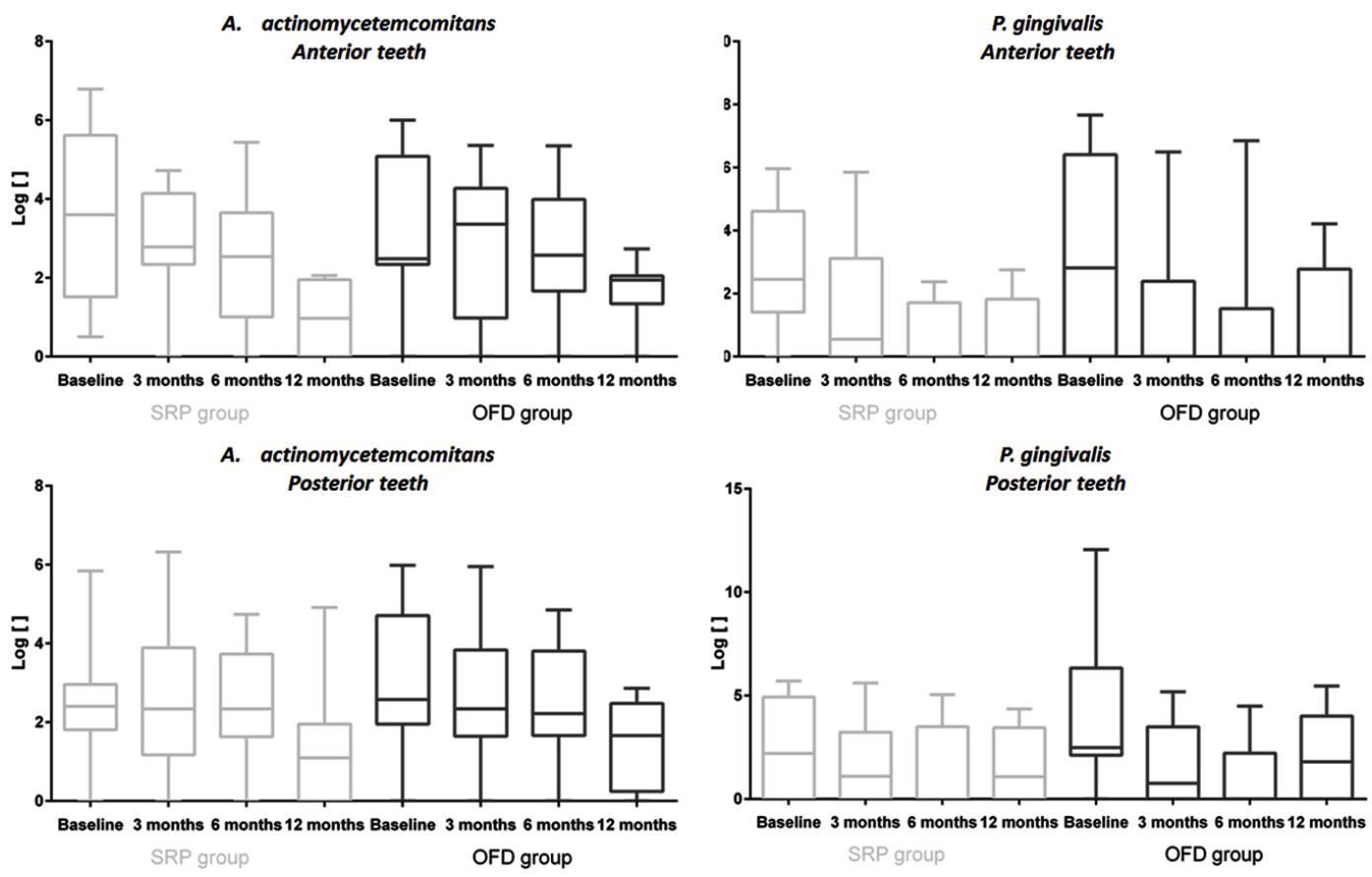

Figure 5. A. actinomycetemcomitans (left) and P. gingivalis (right) amounts (log[ ]) in each group in anterior and posterior teeth during 12 months of follow-up. No difference between groups (Friedman and Wilcoxon's tests, $p>0.05$ ) 
planing (SRP)+antimicrobials compared to SRP alone or SRP+placebo $(12,21)$. This highlights the impact of antimicrobials on pathogens, especially on Aa reduction and indicate a possible additional benefit of it also in surgical therapy, once in the present study no significant changes could be seen in any one period of evaluation. In view of limited literature about the surgical treatment in aggressive periodontitis, no direct comparison could be done. Thus, this combination (surgical and antimicrobials therapy) should be evaluated in future to determine its potential as therapeutic approach for $\mathrm{GAgP}$ subjects.

Periodontal tissue breakdown in GAgP seems to be influenced by Aa's ability to overpass the junctional epithelium and invade connective tissue (25). Accordingly, systemic antimicrobials could have an impact on these pathogens, promoting further reduction in their amount that was not observed in the present study. Even so, the subgingival biofilm presents more than 400 species, and actually, more than $\mathrm{Aa}$ and $\mathrm{Pg}$ have been associated with AgP, in which could be included Streptococcus, Eubacterium, Peptostreptococcus, Selenomonas and other phylotypes that have not yet been cultivated (6). So, further analysis with a high-throughput approach could give us a more definitive idea of how surgical and nonsurgical approaches alter the subgingival environment and, possibly, indicate the most predictable form to treat GAgP subjects.

Indeed, since this is the first randomized clinical trial treating GAgP patients with a surgical approach and its results should be cautiously considered. Firstly, although the present study has used a split-mouth design for compare both therapies, only upper maxilla was included and future analysis should compare upper and lower jaws. Moreover, in this 12-month trial, some drop-outs occurred. So, future controlled clinical trials with a larger sample size (especially after 12 months - when several subjects dropped-out and a borderline post hoc power level was obtained for CAL gain), with longer-term follow-up and/or in association with other adjunct approaches (as antimicrobials) are required to confirm those benefits. In view of quantitative but limited microbial analysis done in the present study, also is important analyze techniques with more wide spectrum (as 165 sequencing) or a higher broad of species, confirming the importance of rigid bacterial control. Moreover, a more rigid plaque control could contribute to better clinical results of two therapies. Although similar plaque levels were found in other GAgP studies (12), these population should be strictly controlled based on their high level of aggressiveness.

Based on the obtained outcomes, it can be concluded that surgical therapy promoted similar clinical benefits, as compared with non-surgical therapy, to GAgP subjects. Moreover, both therapies failed to reduce Aa and Pg levels at different follow-up times.

\section{Resumo}

0 presente estudo teve como objetivo avaliar os efeitos clínicos e microbiológicos de terapia periodontal cirúrgica e não cirúrgica no tratamento da periodontite agressiva generalizada (PAgG). Dezesseis pacientes portadores de PAgG foram incluidos neste estudo clínico, prospectivo, randomizado, de boca dividida. Os quadrantes superiores de cada paciente foram alocados em dois grupos: um grupo de terapia não-cirúrgica (NST) e um grupo de terapia cirúrgica (ST). Os parâmetros clínicos avaliados foram: indice de placa (PI), sangramento à sondagem indice (BoP), profundidade de sondagem (PD), nível clínico de inserção (CAL) e posição da margem gengival (GMP). Também foram determinadas as concentrações de Porphyromonas gingivalis (Pg) e Aggregatibacter actinomycetemcomitans ( $\mathrm{Aa}$ ) no biofilme subgengival. Os parâmetros clínicos e microbiológicos foram avaliados no início, 3, 6 e 12 meses após o tratamento. A terapia cirúrgica foi capaz de promover maior redução de PD em comparação com NST em bolsas profundas aos 12 meses $(p<0,05)$ e em dentes posteriores aos 6 meses $(p<0,05)$. Além disso, houve maior recessão gengival nos dentes posteriores do grupo ST no $6^{\circ}$ mês $(p<0,05)$. Entretanto, ST não promoveu ganho adicionais de inserção (CAL) em nenhum período do avaliação. A avaliação microbiológica não mostrou diferença estatística nos níveis de $\mathrm{Aa}$ e $\mathrm{Pg}$, para ambos os grupos, em todos os periodos de acompanhamento. 0 tratamento cirúrgico promoveu benefícios clínicos similares ao tratamento não cirúrgico em pacientes com PAgG. Além disso, ambas as terapias não conseguiram reduzir os níveis $\mathrm{Aa}$ e $\mathrm{Pg}$ após terapia.

\section{References}

1. Haubek D, Ennibi O-K, Poulsen K, Væth M, Poulsen S, Kilian M. Risk of aggressive periodontitis in adolescent carriers of the JP2 clone of Aggregatibacter (Actinobacillus) actinomycetemcomitans in Morocco: a prospective longitudinal cohort study. Lancet 2008;371: 237-242.

2. Slots J, Ting M. Actinobacillus actinomycetemcomitans and Porphyromonas gingivalis in human periodontal disease: occurrence and treatment. Periodontol 2000 1999;20:82-121.

3. Casarin RC, Ribeiro Edel P, Mariano FS, Nociti FH Jr, Casati MZ, et al. Levels of Aggregatibacter actinomycetemcomitans, Porphyromonas gingivalis, inflammatory cytokines and speciesspecific immunoglobulin $\mathrm{G}$ in generalized aggressive and chronic periodontitis. J Periodontal Res 2010;45:635-642.

4. Gajardo M, Silva N, Gómez L, León R, Parra B, Contreras A, et al. Prevalence of periodontopathic bacteria in aggressive periodontitis patients in a Chilean population. J Periodontol 2005;76: 289-294.

5. Lafaurie Gl, Contreras A, Barón A, Botero J, Mayorga-Fayad I, Jaramillo $A$, et al. Demographic, clinical, and microbiological aspects of chronic and aggressive periodontitis in Colombia: a multicenter study. J Periodontol 2007:78:629-639.

6. Faveri M, Mayer MPA, Feres M, de Figueiredo LC, Dewhirst FE, Paster BJ. Microbiological diversity of generalized aggressive periodontitis by 16S rRNA clonal analysis. Oral Microbiol Immunol 2008:23:112-118.

7. Scharf S, Wohlfeil M, Siegelin Y, Schacher B, Dannewitz B, Eickholz $P$. Clinical results after nonsurgical therapy in aggressive and chronic periodontitis. Clin Oral Investig 2014;18:453-460.

8. Hughes FJ, Syed M, Koshy B, Marinho V, Bostanci N, McKay IJ, et al. Prognostic factors in the treatment of generalized aggressive periodontitis: II. Effects of smoking on initial outcome. J Clin Periodontol 2006;933:671-676.

9. Antczak-Bouckoms A, Joshipura K, Burdick E, Tulloch JFC. Metaanalysis of surgical versus non-surgical methods of treatment for periodontal disease. J Clin Periodontol 1993;20:259-268.

10. Heitz-Mayfield L, Trombelli L, Heitz F, Needleman I, Moles D. A systematic review of the effect of surgical debridement vs nonsurgical debridement for the treatment of chronic periodontitis. J Clin Periodontol 2002;29Suppl3:92-102; discussion 160-162.

11. Buchmann R, Nunn ME, Van Dyke TE, Lange DE. Aggressive periodontitis: 
5-year follow-up of treatment. J Periodontol 2002;73:675-683.

12. Casarin RC, Peloso Ribeiro ED, Sallum EA, Nociti FH Jr, Gonçalves RB, Casati MZ. The combination of amoxicillin and metronidazole improves clinical and microbiologic results of one-stage, full-mouth, ultrasonic debridement in aggressive periodontitis treatment. J Periodontol 2012;83:988-998.

13. Ainamo J, Bay I. Problems and proposals for recording gingivitis and plaque. Int Dent J 1975;4:229-235.

14. Muhlemann HR, Son S. Gingival sulcus bleeding--a leading symptom in initial gingivitis. Helv Odontol Acta 1971;2:107-113.

15. Dolezel J, Bartos J, Voglmayr H, Greilhuber J. Nuclear DNA content and genome size of trout and human. Cytometry A 2003;51:127-128.

16. Christersson LA, Slots J, Rosling BG, Genco RJ. Microbiological and clinical effects of surgical treatment of localized juvenile periodontitis. J Clin Periodontol 1985:12:465-476.

17. Wennström JL, Newman HN, MacNeill SR, Killoy WJ, Griffiths GS, Gillam $D G$, et al. Utilisation of locally delivered doxycycline in non-surgical treatment of chronic periodontitis. A comparative multi-centre trial of 2 treatment approaches. J Clin Periodontol 2001;8:753-761.

18. Villagrana APM, Clavel JFG. Antimicrobial or subantimicrobial antibiotic therapy as an adjunct to the nonsurgical periodontal treatment: a meta-analysis. ISRN Dent 2012;2012:581207.

19. Garcia Canas P, Khouly I, Sanz J, Loomer PM. Effectiveness of systemic antimicrobial therapy in combination with scaling and root planing in the treatment of periodontitis: A systematic review. J Am Dent Assoc 2015;146:150-163.
20. Guerrero A, Griffiths GS, Nibali L, Suvan J, Moles DR, Laurell L, et al. Adjunctive benefits of systemic amoxicillin and metronidazole in non-surgical treatment of generalized aggressive periodontitis: a randomized placebo-controlled clinical trial. J Clin Periodontol 2005;32:1096-1107.

21. Mestnik MJ, Feres M, Figueiredo LC, Soares G, Teles RP, Fermiano $D$, et al. The effects of adjunctive metronidazole plus amoxicillin in the treatment of generalized aggressive periodontitis: a 1-year double-blinded, placebo-controlled, randomized clinical trial. J Clin Periodontol 2012;39:955-961.

22. Serino G, Rosling B, Ramberg P, Socransky SS, Lindhe J. Initial outcome and long-term effect of surgical and non-surgical treatment of advanced periodontal disease. J Clin Periodontol 2001;28:910-916.

23. Badersten A, Nilvéus R, Egelberg J. Scores of plaque, bleeding, suppuration and probing depth to predict probing attachment loss. 5 years of observation following nonsurgical periodontal therapy. J Clin Periodontol 1990;17:102-107.

24. Teughels W, Dhondt R, Dekeyser C, Quirynen M. Treatment of aggressive periodontitis. Periodontol 2000 2014;65:107-133.

25. Saglie FR1, Marfany A, Camargo P. Intragingival occurrence of Actinobacillus actinomycetemcomitans and Bacteroides gingivalis in active destructive periodontal lesions. J Periodontol 1988;59:259-265.

Received January 18, 2019 Accepted June 25, 2019 